\title{
Gymnasieelevers sundhed som sanselige, kollektive og kropspolitiske engagementer
}

\section{Kathrine Vitus}

Aalborg Universitet, København

vitus@socsci.aau.dk

Vitus, Katrhine (2018). Gymnasieelevers sundhed som sanselige, kollektive og kropspolitiske engagementer, Tidsskrift for Forskning i Sygdom og Samfund, nr. 29, 77-98.

Artiklen undersøger gymnasieunges oplevelser med, forståelser af og praksisser omkring sundhed $i$ deres hverdagsliv. Børn og unge eksponeres $i$ dag for sundhedsbudskaber, påbud og overvågning $i$ mange af de sociale sfxrer med sundhed forstået som et individuelt ansvar der udøves gennem at regulere sin kost, rusmiddelbrug og motionsvaner. Gymnasieeleverne oplever gymnasielivet stressende og presset, men de formår også - måske som en reaktion herpå - aktivt at skabe sociale og kropslige rum, som de forbinder med sundhed. I disse rum afstresser de, "er i kroppen" og lader op igen. Disse kropslige og kollektive sundhedsrum er dog ikke identiske med, men står snarere i modsætning til, dominerende individualistiske, biomedicinsk forankrede sundspolitiske påbud og normer. Tværtimod er et væsentligt aspekt af de unges følelse af sundhed, at skærme sig imod disse normer, som også repræsenterer udefrakommende, moralske krav, som virker ikke-kropsliggørende $i$ forhold til deres egne fornemmelser for, hoad der er sundt for dem. Studiet illustrerer vigtigheden af at skoler skaber læringsmiljøer som muliggør at eleverne udforsker deres kropslige og intellektuelle potentialer og kapaciteter, bl.a. gennem at overskride den individualisme som $i$ øjeblikket præger ungdomsuddannelser og sundhedsfremme $i$ Danmark. Gymnasiet bør $i$ stedet søge at skabe rum for kollektiv kropsligt forankret og forankrende laring, i en erken- 
delse af at motivation, engagement og myndiggørende og styrkende affektive relationer - $i$ sundhed, krop og skolepræstationer - hviler på en sam-produktion af engagementer.

Health among upper secondary students: sensual, collective and body political engagements

This article explores upper secondary students' health experiences, understandings and practices in light of the variety of health messages Danish youth encounter in their everyday life. The empirical material is produced through fieldwork in two 2nd year classes at a gymnasium in Copenhagen and consists of student-produced photos, individual interviews and narrative workshop texts. Through Deleuze and Guattari's perspective on health, as produced through affective relations in the interplay between body, self and society, the analysis illuminates the student's experiences of health as the expansion of the body's force and capacity. Thus, the students create health through engagements in bodily and intellectual practices and in active relationships, which mobilise resources in their everyday encounters with people, things and places. While school life pressures, and dominant body and student-subject ideals may hamper such empowering dynamics, the students continuously strive to realise the engagements they experience health to be: health is not so much about what they do to and with their bodies, as it is about how and with whom. The analysis shows that some education and health macro political priorities and approaches are less advisable than others to sustain young people's endeavours towards health, and illustrates the importance of gymnasiums (and other youth educational settings) facilitating learning environments that - also on the students' own terms - enable the exploration of the body and mind's potentials through collectively engaging processes.

\section{Introduktion}

"I juleferien sad jeg og læste og spiste et stykke æbletærte [...] at læse giver mig fantastiske oplevelser [og] forslag til hvordan jeg kan leve mit liv. Det er meget eksistentielt [...] Men ved at spise tærten fyldt med fedt og sukker, som ifølge mange eksperter er meget usundt, følte jeg mig endnu mere sund. Jeg følte mig sund fordi jeg var så optaget, hvilket gør mig så glad og tilfreds og får mig til at føle, at jeg kan klare meget. Og kombinationen, af at føle jeg kan klare meget og at lære, er den ultimative sundhedskombination. Det væsentlige er også, hvad man selv synes er sundt, og ikke hoad andre fortæller dig, er sundt. Det er, hvad jeg mener om sundhed." (Abida, 16 år, i fortælletekst) 
Sådan skriver Abida på 16 år, da hun bliver stillet opgaven at beskrive en oplevelse med at føle sig sund eller usund. Opgaven stilles som en del af et forskningsstudie af, hvordan gymnasieunge oplever, forstår og praktiserer sundhed i deres hverdag inden for rammerne af gymnasielivet. Danske børn og unge bliver i deres hverdagsliv inviteret til at forholde sig til sundhed fra forskellige sider og på forskellige måder. Det sker bl.a. gennem Sundhedsstyrelsens sundhedsfremmende kampagnebudskaber, folkesundhedsforskningens skole- og ungeundersøgelser og tilbud om forbrug af sundhedsprodukter og aktiviteter i alle tænkelige afskygninger. Unge møder her forskellige diskurser , om hvad sundhed er, og hvordan det skabes. De møder bl.a. en dominerende diskurs om, at sundhed handler om det enkelte menneskes fysiske, medicinske tilstand og fravær af sygdom, og at det derfor er et individuelt anliggende, de skal tage ansvar for at opnå ved at regulere deres kost, rusmiddelbrug og motionsvaner i overensstemmelse med særlige forskrifter, uafhængigt af hvilken kontekst de befinder sig i. Denne diskurs - som er funderet i den biomedicinske videnskab - skinner igennem i meget af den viden, de normer og idealer, som dette studies gymnasieunge orienterer sig imod, når de taler om sundhed. I citatet ovenfor gør Abida det samme, når hun refererer til eksperters vurdering af et stykke tærtes (lave) sundhedsværdi. Men ikke desto mindre når Abida frem til den modsatte konklusion end eksperterne: Hun oplever nemlig, at hun bliver sundere af at spise et stykke æbletærte. Hvordan kan det hænge sammen? Hvad er det for dynamikker, Abida her har fat i?

Abida trækker her også på andre sundhedsdiskurser end den biomedicinsk funderede. Hun trækker snarere på sociologisk funderede holistiske, kontekstrefleksive og "positive" forståelser af sundhed, som det hele menneskes fysiske, sociale, mentale og kulturelle trivsel i relation til omgivelserne, understøttet gennem individuelle og kollektive ressourcer, handlekompetence og deltagelsesmuligheder (Jensen 2009a). I denne artikel ser jeg nærmere på, hvordan gymnasieelever oplever sundhed, mens de navigerer i gymnasiehverdagens krav og ungdomslivets udfordringer i lyset af forskellige sundhedsdiskurser og uddannelsespolitiske rammer. Jeg har fokus på, hvordan de unge trods oplevelser af, at disse diskurser og rammer kan virke begrænsende for deres udfoldelse af sundhed, samtidig aktivt indgår i relationer og praktikker med omgivelserne som virker fremmende og understøttende for deres engagementer i både sundhed og gymnasieliv. For at udfolde disse relationer og praktikker, trækker jeg teoretisk på Gilles Deleuze og Felix Guattaris perspektiv på sundhed, som er funderet i en filosofi om samspillet mellem krop, selv og samfund (se også Vitus, 2018). 
Jeg abonnerer hermed også på et grundlæggende systemkritisk perspektiv på, hvordan sundhed etableres. Deleuze og Guattari udviklede oprindeligt deres begreber i en kritik af det etablerede psykiatriske systems dominerende abstrakte og umyndiggørende tilgang til psykisk sygdom. I udviklingen af et alternativ hertil, anskuer Deleuze og Guattari den menneskelige eksistens som aktiv og motiveret snarere end passiv og determineret. De mener, at folk bliver kropslige subjekter gennem etablering af kreative engagementer med deres omgivelser (Deleuze \& Guattari, 1988: 149-151). Denne 'vitalitet' understøttes gennem affektive relationer, dvs. relationer som gør noget ved - har en effekt på - kroppen gennem at give eller fratage kroppen kraft. Den kraft kroppen opnår gennem affektive relationer, kalder Deleuze og Guattari sundhed. Affektive relationer påvirkes af magtstrukturer og diskurser (fx på uddannelses og sundhedsområdet), som hos Deleuze og Guattari bl.a. virker gennem at belejre ('territorialisere') kroppen og potentielt blokere dens kraft. Men kroppen kan lige så vel indgå i andre 'af-belejrende' og 'gen-belejrende' relationer, som genskaber dens kraft (Deleuze \& Guattari 1988: 56). Begæret efter og bestræbelse imod sundhed rummer således også modstanden imod kroppens belejring, ikke kun som en mulighed, men også som et fundamentalt træk, i dets møde med affekter og relationer (Fox, 2002: 360).

Deleuze og Guattaris begreber ræsonnerer ikke blot elevernes oplevelse af, at sundhed handler om at udvide kroppens handlerum og kraft, men kaster også lys over, hvordan oplevelsen af engagement, som fundamental for sundhed og trivsel, er kropsligt forankret og erfaret. Desuden, at engagementer udspringer af elevernes bestræbelser og begær efter at indgå i relationer med omgivelserne; omgivelser, som dog kan opleves som begrænsende for bestræbelserne og begæret. Artiklens hovedargument, som analysen således tydeliggør, er at elevernes sundhed skal forstås som relationel - som kapaciteten til at skabe virksomme relationer og mobilisere ressourcer i hverdagslivets møder med mennesker, ting og steder - snarere end etableret gennem en række individuelle, objektive og subjektive sundhedskomponenter. Denne indsigt kan hjælpe til at forstå, hvordan visse uddannelses- og sundhedspolitiske prioriteringer og tilgange er mindre hensigtsmæssige end andre for unges sundhed i lyset af de dynamikker, de unge selv udpeger som sundhedsfremmende - og det modsatte. 


\section{Baggrund: Gymnasieelevers sundhed og skolemiljø}

Danske unge møder i dag et væld af forskellige krav, muligheder og diskurser omkring både sundhed, trivsel og uddannelse. De mødes med en lang række folkesundhedsinitiativer såsom det obligatoriske folkeskolepensum i sund kost og motion (Tørslev, 2017; Tørslev et al, 2017a, b, c; Vitus, 2017; 2018; Vitus et al., 2017); forebyggelseskampagner, som adresserer børns og unges overvægt, motion, rygning, stof, alkoholmisbrug og ubeskyttede seksuelle adfærd; og spørgeskemaundersøgelser, som overvåger unges sundhedsadfærd og status . Sundhedsstyrelsens initiativer tager generelt udgangspunkt i KRAM-faktorerne, som gennem biomedicinsk defineret individuelle livsstilsdimensioner promoverer den rette kost, ingen rygning, begrænsede mængder alkohol og daglig motion, som vejen til sundhed. Denne tilgang afspejler den øgede neoliberalisering i det danske sundhedssystem, hvor fokus er på personligt ansvar for egen sundhed (Vallgårda 2010, 2011), frem for på strukturelle faktorer og sociale determinanter som kan rammesætte og føre til sundhed (se fx HBSC, 2016). Samtidig appellerer både officielle sundhedsbudskaber og forbrugskapitalismens sundhedsindustri til unges nydelse i relation til både seksualitet, rusmidler og ungdomskulturelle fællesskaber. Det sker bl.a. gennem skabelse af fantasier, som dirigerer de unges sundhedsbestræbelser, begær og adfærd i bestemte retninger, under et løfte om herigennem at opnå lykke; et løfte, der samtidig fremstår som den enkeltes pligt at indfri (Vitus, 2017).

I international sammenligning er danske unges sundhed relativ god når det gælder visse fysiske sundhedsparametre. Fx har danske 15-årige i sammenligning med unge fra 43 andre lande relativt sunde kostvaner og er mindre overvægtige (HBSC, 2016: 95), til trods for at de motionerer mindre (HBSC, 2016: 137). Danske unge er også mere optagede af vægtreducerende praksisser (HBSC, 2016: 103) og af, om de er for tykke (HBSC, 2016: 99). Når det gælder danske gymnasieunges mentale helbred er billedet ret entydigt negativt. I 2014 angav 5,7 \% af undersøgelsens 70.546 gymnasieelever at de havde depression (Bendtsen et al., 2014: 445), $39 \%$ følte sig stressede hver uge og 12\% hver dag (Bendtsen et al,. 2014: 42). En mindre undersøgelse fra 2017 af 2030 gymnasieelever viste, at 34\% ofte følte stress, mens $47 \%$ af og til følte stress (Willer og Østergaard, 2017). I en 2016-undersøgelse oplever 1/3 af danske unge sig pressede af skolearbejdet (HBSC, 2016: 61). Tal for forskellige skolerelaterede parametre vidner også om udtalte udfordringer i forhold til gymnasieunges mentale helbred. I 2015 var frafaldet på danske gymnasier $20 \%, 34 \%$ af de studerende kedede sig, $48 \%$ var aktive på sociale medier i timerne, 
og $40 \%$ fandt undervisningen monoton. Endeligt oplevede $29 \%$ af de studerende ikke, at de har nogen demokratisk indflydelse i skolelivet (UVM, 2015). Tallene her synes at ræsonnere med tendenser, der omtales som unges 'motivationskrise' (Sørensen et al., 2013). Denne krise manifesterer sig gennem elevernes mangel på engagement og deltagelse i undervisningen, manglende forberedelse og høje fraværstal, samtidig med et ønske om gerne at ville engageres, og en bevidsthed om, at uddannelse i dag er en nødvendighed for at klare sig. Men eleverne kan ikke se, hvordan det, de lærer i gymnasiet, er relevant og brugbart - også ud over en eksamenssammenhæng (Hutters et al. 2013; Murning 2013; Murning \& Hutters 2014; Nordahl et al 2010; Ulriksen et al 2009; UNI-C 2009).

Hvis vi skal forsøge at forstå disse tal og deres sammenhæng - fx mellem stress, kedsomhed og frafald - bør vi måske rette blikket mod det skolemiljø, som udgør den hverdagslige strukturelle og diskursive ramme for gymnasieunges trivsel og mistrivsel. Det danske uddannelsessystem har de seneste 30 år gennemgået fundamentale forandringer. I 1990'erne var det uddannelsespolitiske fokus på frit valg og uddannelse til alle unge, og gymnasieuddannelsen blev betragtet som led i den basale dannelse af unge mennesker til at kunne deltage i et demokratisk samfund. Men, italesat som en reaktion på øget global konkurrence (se Pedersen, 2011), banede en reform i 2000 vejen for en konkurrencediskurs, som i stigende grad op igennem 2010'erne, transformerede uddannelse til et makroøkonomisk instrument. Siden er ungdomsuddannelserne blevet stadig mere strømlinede og tilpasset arbejdsmarkedsbehov gennem individuelle uddannelsesplaner, niveaudeling, mentorordninger, vejledning og individuelt designede processer, der har til formål at skabe 'uddannelsesparate' unge. Desuden er en 'fremdriftsreform' indført, som belønner unge der bevæger sig hurtigt igennem uddannelsessystemet. Disse udviklinger har ført til øget polarisering i uddannelsessystemet og et større fokus på præstation, nytte, tests, rangordning og standardisering i skolen (Sørensen et al., 2013).

Ligesom gymnasieelever i andre danske undersøgelser (se også Bendtsen et al., 2014; Ingholt 2007; Pedersen, 2015; Willer \& Østergaard, 2017:12) fortæller eleverne i dette studie, at gymnasielivet fordrer af dem, at de er i stand at praktisere individuelt ansvar og beslutningsdygtighed i designet af deres personlige uddannelsesveje i lyset af deres fremtidsplaner (Nielsen et al, 2017). Ligeledes, at de kan navigere, organisere og praktisere sundhed, trivsel og nydelse i et komplekst hverdagsliv i balancen mellem skole, lektier, fritidsaktiviteter, familieforpligtelser og venskabsrelationer. 


\section{Metode og data}

Jeg har undersøgt gymnasieelevers sundhedsforståelser, erfaringer og praksisser i to naturfaglige 2.g-klasser på et københavnsk gymnasium, med deltagelse af lige mange drenge og piger, og lige mange elever med baggrund i primært ikkevestlige lande og elever med etnisk dansk baggrund i alderen 16-17 år. Eleverne deltog frivilligt i undersøgelsesaktiviteter (Alderson \& Morrow, 2004), og navne og steder er anonymiserede. Under to måneders feltarbejde deltog alle 37 elever i kvalitative deltagende og visuelle forskningsaktiviteter. Jeg bad eleverne om at tage fotografier af ting, steder, situationer etc. som de forbinder med sundhed og/ eller usundhed. Det resulterede i billeder af mad, natur, jævnaldrende, familiemedlemmer, begivenheder, turistmål, sportsaktiviteter, ferie, religiøse ritualer, krops/sundheds redskaber (fx træningsredskaber, boksehandsker), nydelsesmidler (fx cigaretter, flasker med alkohol, slikbarer, junkfood) og hverdagsting (fx cykel, computer, bøger). Billederne dannede udgangspunktet for efterfølgende interview med mig, som de herved satte dagsordenen for (Harper, 2002:15), mens mine spørgsmål mest var opfølgende og uddybende. Billederne inviterede desuden til samtaler om sanselige oplevelser, stemninger og engagementer, som ellers kunne være svære at sætte på ord (Guillemin \& Drew, 2010: 178).

Som en del af en AT-uge om krop og sundhed, som jeg organiserede sammen med klassens lærere, blev eleverne opdelt i grupper, hvor de skrev individuelle fortælletekster om deres oplevelser med sundhed og usundhed og diskuterede dem i fællesskab. Skriveprocessen var opdelt i tre runder: Først skrev eleverne nøgleord om sundhed og usundhed; dernæst en fortælling i 1. person-perspektiv ("jeg"); slutteligt omskrev de fortællingen til 3. person-perspektiv ("han"/"hun"). Diskussionerne mellem skrivefaserne, igangsat af moderatorer, handlede om de enkelte tekster og om potentielle fællestræk eller bagvedliggende kollektive normer i de individuelle erfaringer (Haug, 1992; Krøjer \& Hutters, 2006).

I analysen fokuserede jeg på ambivalenser, modsætninger og tvetydigheder (Timmerman \& Tavory, 2012) i elevernes opfattelser af hvad sundhed og usundhed er, hvilken rolle det spiller, og hvordan det skabes, opstår i hverdagslivet og opleves kropsligt. På tværs af det empiriske materiale (fotografier, interviewudskrifter og fortælletekster) udkrystalliseredes forskellige domæner for elevernes oplevelser, forståelse og praksisser omkring sundhed og usundhed: de unge(s) selv, familie og jævnaldrende, arbejde og fritid, gymnasiet, og endelig sundhedsog uddannelsesdiskurser. Samtidig syntes elevernes engagementer og positive og negative oplevelser med sundhed og usundhed at udspringe fra forskellige kroppe, 
som - i lyset af Deuleuze og Guattaris perspektiv - relaterede sig forskelligt til omverdenen, og herigennem skabte forskellige platforme for engagement og for at fremme eller tabe kraft og vitalitet.

Jeg præsenterer nedenfor analysen i fire dele. I første analysedel fungerer Abidas fortælletekst som en illustrativ case på etableringen af kraftgivende affektive relationer til omgivelserne gennem både kropslige praktikker og i samspil med modsatrettede diskurser om sundhed. I anden, tredje og fjerde analysedel ser jeg på gymnasieelevernes sundhedsengagementer og affektive oplevelser med (u) sundhed inden for forskellige domæner, med fokus på deres sansende, sociale og politiske krop. Jeg undersøger også deres måder at balancere, forhandle og yde modstand imod begrænsende strukturer og diskurser.

\section{Analyse}

\section{Affektive sundhedsrelationer}

Læst gennem Deleuze og Guattaris optik, illustrerer Abidas lille tekst - som beskriver "Det er hvad jeg mener om sundhed" - hendes kropslige engagement i sundhed som drevet af et begærende, positivt og bekræftende potentiale. Ved fortællingens start, "I juleferien sad jeg og læste og spiste et stykke æbletærte [...] at læse giver mig fantastiske oplevelser [og] forslag til hvordan jeg kan leve mit liv. Det er meget eksistentielt [...]", forankrer Abida oplevelsen af sundhed i sin fordybelse i en aktivitet. Ifølge Deleuze og Guattari trives kroppe kun gennem engagementer: Kun gennem at udleve dette positive begær, kan kroppe være kreative og aktive snarere end passive og reaktive, i forhold til at imødekomme deres virkelige (ikke blot symbolske) behov og blive befriet fra undertrykkende samfundsstrukturer (Deleuze \& Guattari, 1988: 254).

Som Deleuze og Guattari påpeger, handler det at realisere sundhed basalt set om at udforske 'hvad kroppe kan'. Det handler om at udvikle og udleve kroppes affektive relationer, dvs. evne til at påvirke andre ting og blive påvirket snarere end blot emotionelle reaktioner (Deleuze \& Guattari, 1988: xvi, 257). Skabelsen af subjektivitet sker i samspillet mellem en persons refleksive meningstilskrivning og hans eller hendes kropslige engagement i de fysiske, psykologiske og sociale omgivelser. Kroppes affektive relationer består således af summen af deres psykologiske, emotionelle og fysiske forbindelser med sig selv og omgivelserne, dvs. 
med mennesker, ting, aktiviteter og abstrakte ideer og sociale konstruktioner (Fox \& Ward, 2008: 1008):

"Vi ved intet om en krop, før vi ved, hoad den kan gøre, med andre ord, hoad dens affekter er, hoordan den kan eller ikke kan forbinde sig til andre affekter, til en anden krops affekter, enten for at ødelæge denne krop eller blive ødelagt af den, enten for at udveksle handlinger og lidenskaber med den eller for at smelte sammen med den for at skabe en mere kraftfuld krop", skriver Deleuze \& Guattari (1987: 257).

For Abida var engagementet i at læse - "jeg var så optaget, hvilket gør mig så glad og tilfreds" - stimulerende og bekræftende, men det skabte også en stærk følelse af kapacitet og styrke: "og får mig til at føle, at jeg kan klare meget", skriver hun. Hun definerede denne følelse af kapacitet som sundhed: "Jeg følte mig sund, fordi jeg var så optaget", og følelsen opstod på trods af, at hun samtidig spiste et fedende, sukkerfyldt - og ifølge herskende sundhedsdiskurser derfor usundt - stykke æbletærte: "Men ved at spise tærten fyldt med fedt og sukker, som ifølge mange eksperter er meget usundt, følte jeg mig endnu mere sund. Jeg følte mig sund, fordi jeg var så optaget”. Æbletærtens aktivering af Abidas smags og lugtesans, forstærkede måske endda hendes kropslige engagement. Abidas sundhedsbegreb indfanger totaliteten i situationen: hendes oplevelse af engagement, sanselige og kognitive stimulation og kapacitet: "Og kombinationen af, at føle jeg kan klare meget og at lære, er den ultimative sundhedskombination."

Den form for kropsligt affektivt engagement, som Abida her sætter ord på, har ifølge Deleuze og Guattari sit udspring i kroppen som en åben struktur, der i princippet kan forme utallige forskellige affektive relationer med omverdenen. Denne form for kropslig væren er fundamentalt set forskellig fra den mere lukkede, prædefinerede, velafgrænsede krop(slige væren), som skabes gennem sundhedspolitikker, religion, loven og den biomedicinske videnskab (Deleuze \& Guattari, 1969, i Fox, 2002: 351). Men trods Abidas konstruktion af sundhed som hendes helt egen, spontant definerede - gennem genoplevelsen af en affektiv relation præget af engagement og fordybelse i læsning/bog og spisning/æbletærte - konstruerede hun sin sundhedsdefinition i dialog med og opposition til dominerende sundhedsdiskurser.

Også i dialogen med/mod eksperternes sundhedsopfattelse, skabte hun en bekræftende affektiv relation. Hendes fortælletekst fortsætter nemlig: "Det væsentlige er også hvad man selv synes er sundt, og ikke hvad andre fortæller dig er 
sundt". Det at spise (usund) æbletærte producerer (ud over engagement) altså en kropspolitisk position: nemlig Abidas insisteren på at stole på sin egen sundhedsdefinition uafhængigt af sundhedseksperters (som reducerer sundhed til mængderne af fedt og sukker). Abidas sundhedsbegreb kan siges at samstemme med Deleuze \& Guattaris begreb om 'kropsetik', som ifølge Buchanan (1997), definerer kvaliteten af affektive relationer mellem kroppe og deres omgivelser, som en kapacitet til at forme nye relationer og herigennem sikre en åben fremtid. Den sunde krop har nemlig utallige affekter og lige så mange relationer, som giver kroppen kraft og kapacitet (Buchanan, 1997: 82).

Kroppe og engagementer er således ikke uberørte af, men formes også gennem hierarkiske magt-dynamikkers aftryk i hverdagslivet og omgivelserne. Kroppe manifesterer sig gennem 'belejringer', fx når de unges affektive relationer med omgivelserne domineres af herskende perspektiver og fordringer fra videnskab og kultur om den ideelle krop, og fra sundheds- og uddannelsespolitik om den ideelle gymnasieunge. Disse normer udgør for de unge potentielt væsentlige platforme for at opnå egen og andres anerkendelse. Men kroppe kan også møde disse belejringer med modstand og vriste sig fri af dem gennem 'af-belejring' og potentiel 'gen-belejring' i nye former, om ikke andet så momentant og situationelt (i 'flugtlinjer') (Deleuze \& Guattari, 1988: 56). I disse momenter og situationer kan, ifølge Deleuze og Guattari, et andet kreativt, meningsskabende, begærende subjekt frigives og opdage sig selv. I sådanne øjeblikke af refleksivitet kan en (ny) identitet manifestere sig - "Så det er mig! Så det er hvad det handler om!" cf. Bogue (1989: 95) - som når Abida genkender sig selv i sit eget kropsligt erfarede sundhedsbegreb: "Det er, hvad jeg mener om, sundhed." I sin fortælletekst italesætter Abida sin sansende krop, i beskrivelsen af hvordan æbletærte og læsning vækker hendes sanser og følelser. Men i beskrivelsen af sin nydelse ved tærten og dens bestyrkelse af hendes engagement aktiveres også hendes politiske krop, idet hun etablerer en modposition i forhold til en latent belejring fra kalorietælling og sukkerforbud. I opdagelsen og genkendelsen af sig selv, i en afbelejring og genbelejring i forhold til det, som Abida oplever som en udefrakommende sundhedsdefinition, etablerer hun sit helt eget engagement i sin egen sundhed.

I de følgende tre analyseafsnit viser jeg, hvordan andre af gymnasieeleverne etablerede sundhedsengagementer gennem affektive oplevelser i forhold til deres sansende, sociale og politiske krop inden for forskellige af gymnasielivets domæner, og deres måder at balancere, forhandle og yde modstand imod begrænsende strukturer og diskurser. 


\section{Sanselige engagementer}

Når jeg bad eleverne om at beskrive deres oplevelser af og måder at praktisere sundhed, beskrev de hverdagslige situationer med affektive relationer præget af sanselige kropslige engagementer. Når Balder lavede push-ups i fitnesscentret, gjorde han bevægelserne langsomme for at intensivere oplevelsen af både styrke og smerte: "Det gør det endnu hårdere, fordi det kræver total koncentration og fokus, men det får mig til at føle mig helt levende og i kontakt med min egen styrke. Det får mig virkelig til at mærke min krop og hvordan den kan arbejde". Ali praktiserede et morgenritual, der vækkede hans krop til et stærkt nærvær: "Det fedeste er om morgenen at drikke sin kaffe meget varm og så tage et stykke rigtig mørk chokolade til, før man indtager noget andet og lige efter man er vågnet [...] og så lige en cigaret, hvis man ryger." Muna beskrev et andet ritual, som hun gentog næsten hver eftermiddag for at skabe "ren nydelse", afslapning og "genopladning". Ved at spise en lille portion kartoffelchips i nøje afmålte doser og i tempi, som fastholdt hende i fordybelsen i den sanselige oplevelse af deres salte, bitre smag og sprøde tekstur, tillod hun sig selv at gå helt ned i tempo. Ligesom Abida oplevede andre studerende læsning af bøger som noget, der gav en fred, som de associerede med sundhed. Nanna forklarede: "Jeg elsker, når vi bare skal læse til skolen uden bestemte mål eller spørgsmål eller ud fra en analysemodel [...] så læser man for at blive klogere og for sin nysgerrighed, om hvordan andre mennesker tænker og handler, det er ligesom et spejl i forhold til, hvordan man kan leve sit liv, som giver mig følelsen af flere muligheder, ligesom".

I disse sanselige engagementer søgte eleverne at dæmme op for den stress, som de - ligesom elever i andre gymnasiestudier - oplevede gymnasielivet producere. Så Munas chips ritual tilbød en sanselige oplevelse i et helt andet tempo midt i de mange opgaver og krav, hendes liv mødte hende med. "Det er det tidspunkt hvor jeg sådan kan trække mig tilbage og så glemme alt om afleveringer og sådan noget, [hvor jeg] glemmer alle tanker, som ellers normalt stresser mig." Alis morgenchokolade og -kaffe lod ham lade op til en skoledag, han oplevede som "meget presset", gennem at sætte en særlig kropslig stemning. Balder prøvede at overføre den kropslige oplevelse af styrke og kraft fra fitness centrets intense pull-ups til skolearbejdet, fx når han lavede store afleveringer, men det lykkedes sjældent: "det er som om, alle de der definerede regler for, hvordan resultatet skal være, står i vejen, [når processen i stedet bør være] styret af de øjeblikke, man selv skaber".

Elevernes oplevelser af sanselige affektive relationer - stimuleret gennem at træne kroppen, spise og læse på måder, som eleverne opfattede som sunde - ud- 
foldedes inden for et rum af potentialitet. I dette rum stod deres kroppe åbne for det, som måtte udvikle sig i momentet og det muliggjorde, at de uforstyrret kunne gøre sig ét med en aktivitet. Disse sanselige engagementer organiserede sig omkring etableringen af intensitet, tempi og rytme. Intensitet var selve det, der fastholdt engagementet, tempi var muligheden for at variere og balancere fart og langsomhed i aktiviteter (mellem fx lektier og afslapning). Rytme, som var med til at skabe variation og dermed både potentialitet og engagement i aktiviteterne, var også sensitiv i forhold til forstyrrelser.

Dalmar beskrev i sin fortælletekst hvordan sommerferiens udenlandsrejse forstyrrede hans (sundheds)rytme og fik ham til at slippe "det øje han havde på sine spisevaner", men selvom "han forsøgte at få lysten og motivationen tilbage, var det endnu ikke lykkedes". Da træningsrytmen var blevet brudt, forsvandt også tilfredsstillelsen, fortalte han mig under et interview: "Jeg ved ikke hvorfor, men jeg kan ikke længere lide [at træne], sådan som jeg plejede". Dette tab af træningsengagement gik også ud over hans skolemotivation: "Jeg kan normalt godt lide skolen i begyndelsen af året, og først senere begynder jeg at kede mig, og så mister jeg også motivationen til at træne, indtil sommerferien starter [men så] slapper [jeg] af igen og genoptager min træning. Men efter denne sommer tabte jeg interessen for at træne og kom aldrig rigtig ind i skolestemningen igen." At være uberørt og uengageret $i$ at danne relationer med omverdenen, frarøver ikke kun motivation, mener Deleuze og Guattari, det forhindrer også en persons frihed og selvbestemmelse (jf. Buchanan, 1997), som nemlig ikke kan skabes gennem vilje, men gennem realiseringen af engagementer og affektive relationer (Deleuze, 1988: 69, 1990a: 238).

I Munas fortælling om sundhed i sommerferien opstod den modsatte situation. Væk fra skole, stress og rutiner, som drænede hende for energi, blev hun i stand til ikke kun at relatere sig til omgivelserne og sin krop på nye måder, men også at skifte kønsmæssigt perspektiv (til hankøn i fortællingens 3. person-perspektiv): “Det giver ham en helt bestemt spirituel følelse at lave noget han godt kan lide, noget han brænder for, hverdagen står dog ofte i vejen for dette. Derfor er sommerferien et frirum for ham. Et frirum hvor han lader op til resten af året, et frirum der giver ham følelse af selvbeherskelse og magt over sig selv og sin egen krop. Selvbeherskelse fordi at han på trods af at have fuldstændig frie rammer stadig vælger ikke at være usund. Magt over sig selv fordi han selv bestemmer hvad dagsorden står på”. Den potentialitet Muna - endda transformeret til hankøn - her beskriver sommerferien skabe rum for, ræsonnerer med Deleuze og Guattari's forståelse af identitet som en aktiv, kreativ proces drevet af "kapaciteten til at danne 
nye relationer og begæret efter at gøre det" (min oversættelse, Buchanan 1997: 83). I dette lys afgøres en kropsliggjort subjektivitetskarakter ikke af hvad den er, men hvad den gør og ellers kan gøre; hvad den kan blive (Fox \& Ward 2008; 1010). Åbne muligheder for at kunne blive en anden, opleves derfor som frisættende, også selvom det kun varer en sommer.

Fælles for Abidas, Balders, Alis, Munas, Nannas og Dalmars beskrivelser er oplevelsen af tilstedeværelse, kreativitet og potentialitet, muliggjort og kultiveret gennem sanselige kropsengagementer i sprækkerne af hverdagslivets opgaver og rutiner, bl.a. for at balance pres og stress fra gymnasielivet. Samtidig stod disse ritualiserede praksisser - $\mathrm{fx}$ at spise chokolade til morgenmad og kartoffelchips hver eftermiddag eller som Sarah, at drikke sodavand under lektielæsningen som "en måde ikke at tage skolen alt for alvorligt, på den dårlige måde, som et pres" - i modsætning til de officielle sundhedsforskrifter. Mens de unges ritualiserede relationelle engagementer blev etableret og fungerede som af-belejrende beskyttelse mod belejring fra diskurser om fx konkurrence og præstation i gymnasiet, stod atter andre diskurser altid klar til at gen-belejre kroppen. Dette galt fx når Munas nydelse og afstresning ved sit chips-ritual, lod sig belejre af dominerede sundhedsforskrifter, som fremfor at tillade hendes sansning af ritualets kvalitet, rettede et evaluerende blik på dets kvantitet, dvs. hvor mange kartoffelchips, hun havde spist. Den affektive relation blev herved negativ frem for kraftgivende. For som Muna fortalte under interviewet: "det giver mig sådan en dårlig samvittighed, fordi jeg ved det er usundt".

\section{Kollektive engagementer}

Abidas nøgleord (skrevet som indledning til fortælleteksten) var disse: "sundhed $=$ mange social relationer, usundhed = minus socialt samvær med andre, se TV alene". Også for eleverne i dette studie (se Ingholt, 2007; Sørensen et al, 2011; Willer og Østergaard, 2017), var "det sociale sammenhold", "at have venner" og "fællesskab" vigtigt for deres sundhed, og associeret med at "have det godt", "at føle sig hjemme", "føle man hører til" og "opleve at ens liv ligesom hænger sammen". Disse bestræbelser karakteriserer jeg som kollektive engagementer. Når kollektive engagementer blev belejret af skolelivets individualiserende strukturer og diskurser, mødte eleverne dem ofte med både af-belejrende strategier og forsøg på at gen-belejre dem på nye måder i nye affektive relationer. Deleuze og Guattari identificerer et potentiale for modstand i sådanne processer omkring af- og gen-belejring; hvad enten det er som et resultat af individuel refleksivitet, gennem andres handlinger 
eller handlinger med andre. Modstanden består i potentialerne for momentane eller livsændrende flugtlinjer, som bærer kroppen ind i nye uforudsete muligheder for nye identiteter og 'bliven-andre' sammen (Deleuze \& Guattari, 1988: 55).

Som et eksempel på at føle sig sund, beskrev Sabina, hvordan hun jævnligt mødtes med venner, som hun deler en særlig musik og danseinteresse med: "Vi er sammen på en helt særlig måde fordi vi elsker at danse sammen". Ud fra et foto af hende og vennerne hængende ud i et af byens store parktræer, forklarede hun, hvordan den lange gåtur derhen, deres snakke i træet og efterfølgende dans skabte nydelse og fællesskab: "Det giver mig så meget glæde og energi", fortæller Sabina, "selv vores aldersforskel [ml. 13 og 17 år] betyder intet, for vi kender hinanden så godt, og det er lige meget, når vi danser". Det kollektive engagement, som blev skabt gennem dansen i Sabinas sociale relationer, muliggjorde en af-belejring af bl.a. de gængse aldersnormer (Caspi, 1990), som i ungdomsårene ellers skaber distinktioner i unges selvforståelse og relationer. En fælles identitet blev i stedet skabt gennem gen-belejring i de affektive relationer, som forenede de unge kvinder, musikken, parken og dansens symmetriske bevægelser af kroppe.

Under interview fortalte Nanna om sin oplevelse af sundhed, som bl.a. at "føle mig hjemme, at jeg på en måde ikke føler, at der er noget, der ligesom 'aahhrr', trækker mig i en anden retning". I folkeskolen følte Nanna sig holdt uden for af sine klassekammerater: "Det var som om jeg var usynlig. De opførte sig simpelthen, som om jeg ikke var der". Disse erfaringer med ikke at føle sig "ligesom, fuldstændig tryg" med sine klassekammerater, var afsæt for Nannas ønsker og planer om at skabe nye relationer - og dermed nye identitetsmuligheder - ved at involvere sig i skolens festudvalg. Af-belejring, som rummer potentialet for, at refleksivitet og forandring (Deleuze \& Guattari 1988: 56), kan blive til på mange måder; gennem fx interaktioner eller oplevelser i nye relationer, miljøskifte (Deleuze \& Guattari 1988: 55), konfrontationer (Drury \& Reicher 2000) og sågar interviewspørgsmål (Fox \& Ward 2008: 1009).

Andre elever oplevede også ind imellem gymnasiemiljøet som utrygt og præget af socialt pres, bl.a. i kraft belejringer fra normer om individuel præstation og indbyrdes konkurrence. I sin fortælletekst med titlen "Umuligt, nødvendigt", beskrev Jens en episode fra idrætstimen. En gruppe drenge cyklede i skoven og stoppede ved en lille $s \varnothing$, hvor en af drengene gik armgang ad et 18 meter langt reb over vandet, mens de andre heppede. Jens tog udfordringen op, men midtvejs på rebet blev han udmattet og mistede den ene hånds greb om rebet. Han hang nu i en hånd over en stor bjælke i søens overflade, mens de andre drenge grinede af ham og råbte, at han skulle give slip med den anden hånd. Det lykkedes dog 
Jens at klatre forbi bjælken, før han lod sig dumpe ned i vandet: "så bange som jeg nogensinde har været. Mens jeg kommer mig over chokket, hører jeg de andre grine af mig, men jeg er ligeglad, for jeg havde virkeligt lært noget om mig selv". I sin 3. personfortælling lagde Jens et kritisk reflekterende lag på sin beskrivelse af episoden, som potentielt etablerede en momentan flugtlinje til at blive-en-anden ung mand. Under en ny titel, "Ham, idioten", skriver Jens: De siger, at han skal kravle over rebet, det ser ret farligt ud. Hvad tænker han på? Hvorfor kravle over rebet bare fordi den anden dreng gjorde det, eller hvad? Sikkert fordi han vil vise sig og for at bevise hvem der er stærkest, sådan som drenge nogen gange gør [...]."

Nour var en af de elever, som aktivt søgte gen-belejringer fra pres omkring skolepræstationer gennem (nye) kollektive engagementer: "Jeg er normalt en ret lukket person, så jeg kan ikke lide at lave præsentationer [og] jeg endte med at få meget dårlige karakterer [på det gamle gymnasium]. Vi var en gruppe piger, som hang ud sammen, men vi hjalp ikke hinanden til at klare skolen bedre". Hun foretog derfor et miljøskifte til det nuværende gymnasium, hvor nye relationer til elever og lærere muliggjorde nye former for trivsel og engagement. Amina, som beskrev sig selv om én med lavt selvtillid, både akademisk og "med mit udseende", skiftede også gymnasium, så hun kunne føle sig mere tryg sammen med sin kusine. Men hun var sensitiv i forhold til de sociale dynamikker, som skabte hierarkier og fikserede identitetskategorier: "Jeg føler nemt, at jeg ender op som en af de dårlige elever, som ikke kan klare skolepresset".

Fordi relationen mellem en person og hans eller hendes omgivelser er dynamiske og udfordrende, er bevægelser mellem belejring, af-belejring og gen-belejring en almindelig del af eksistensens dagligdags grundstof, udfoldet omkring andenskabelse i liv og død, sundhed og sygdom (Fox 2002:353). Dynamikker af belejring, af-belejring og gen-belejring vævede sig således også sammen med gymnasieelevernes oplevelser af sundhed, og føltes uadskillelige fra den sociale krops kollektive engagementer. Affektive relationer skabt gennem kollektive engagementer oplevedes essentielle for følelsen af tilhør og forening, åbenhed og bevægelighed i de aktiviteter og mellem personer, der var involverede. Men skabelse og vedligeholdelsen af sådanne affektive relationer, krævede kontinuerligt personlige og kollektive faciliterende og kompenserende bestræbelser.

\section{Kropspolitiske engagementer}

I Deleuze og Guattari's perspektiv, rummer begæret efter og bestræbelse imod sundhed i alle dets affektive relationer en latent, kontinuerlig modstand imod 
kropssubjektets fratagelse af engagement og kraft (Fox, 2002: 360). I disse bestræbelser spiller det, jeg kalder den politiske krop, også en rolle. Den politiske krop var således involveret $i$ at bevogte den sanselige og sociale krops kraft gennem af-belejrende aktiviteter. Men i den kontinuerlige drift mod at finde kraft, indgik de unges kroppe også bekræftende relationer og engagementer (gen-belejringer) inden for rammerne af sundhed som "defineret af samfundet" (med Jespers ord). Disse, den politiske krops engagementer, handlede om at "passe ind i", "leve op til" og være eller blive "rigtige" i adfærd, kropsformer og -attitude i forhold til samfundets normer og idealer.

At indgå i belejrende relationer med dominerende sundhedsdiskurser tillod eleverne $\mathrm{fx}$ at opnå en højere social status. Salmans engagement og evner i fodbold - en "sund" aktivitet - gjorde ham i stand til at danne sociale relationer til "de gode drenge" i sit boligkvarter og høste anerkendelse fra sine forældre, lærere, andre lokale voksne og i sidste ende sig selv. Både fodbolden og disse "gode venskaber" afskærmede ham fra "dårligt selskab", at "blive en af de der taber indvandrerdrenge", og banede vejen for andre anerkendte sociale positioner, såsom at være en af de kloge elever i klassen. "Det var som om, fodbold lærte mig, hvordan man har succes med det, man laver, og det gør det OK at arbejde på at få en god uddannelse og karriere", forklarede han mig i interview.

Dominerende normer om den sunde krop krydsedes med andre socialt bekræftende positioner og genskabte hegemoniske kropspolitiske engagementer, som gav kroppen kraft. Clara, som fulgte et elitestuderende program, var optaget af at præstere godt, men også at følge kønnede normer for sundhed. "Jeg havde en periode [som teenager], hvor jeg læste ret mange modeblade [...] og så tænkte jeg 'måske skulle man egentlig også tænkte på, hvordan man ser ud' og sådan noget, altså sådan med kroppen og sådan noget [...] fordi jeg ikke ville være tyk [...] så begyndte jeg, sådan, at tænke 'ej, måske skulle man, sådan, gå lidt mere pigeligt klædt' og sådan noget, nederdele og kjoler [...] og nu vil jeg hellere gå med det end med bukser". Ved at følge normer om, at spise 'let' (spise lidt af alt "ligesom franske kvinder"), kunne Clara både forhindre at tage på i vægt, men også skabe en særlig feminin kropsfornemmelse, som hun oplevede selvbekræftende i relationer med fx jævnaldrende og skolelærerne: " så er man - ikke rigtig beskyttet, men sådan lidt mere sikker i sig selv, så har man ligesom sin ryg dækket [...] så selvom man får problemer, ser man godt ud". Benjamin talte også om den styrke, han oplevede ved at følge dominerende kropsidealer gennem at løfte vægte i træningscentret for at få store muskler og fremstå mere maskulin. Belønningen for 
sin indsats var de anerkendende blikke, han fik fra andre, som gav ham øget selvagtelse.

Emilie elskede Parkour for sportens iboende kreativitet og improvisation, som muliggjorde en åbenhed i udøvelsen: "det er ikke er noget man kun gør, når man allerede kan det, [derimod] tester man hele tiden sine evner til grænsen af, hvad man kan og udfordrer sig selv [...] og så opdager man, at man godt kan, og så bliver man så glad, [fordi] man har rykket nogle grænser". Denne potentialitet $\mathrm{i}$ afsøgningen af, hvad kroppen kan, stod i modsætning til andre sportsgrene, fx: "I atletik er der ligesom én måde, man springer det rigtige længdespring på, og træneren bestemmer det hele [...] der er ingen fleksibilitet [...] i Parkour skal man ligesom selv opfinde det hele." At praktisere Parkour var imidlertid også Emilies måde at engagere den politiske krop, gennem at modsætte sig herskende kønsnormer: "Jeg har altid hadet, at som pige skal jeg helst have kjole og høje hæle på, for det får mig til at føle mig fanget [...] man kan ikke løbe i høje hæle og at løbe får mig til at føle frihed", og lade sig genbelejre på nye møder, for "i Parkour kan jeg bevæge mig frit, selvom det er en drengesport."

Salman, Clara, og Benjamins oplevelser med at finde kraft og vitalitet gennem at tilpasse sig gældende normer for sund og rigtig adfærd - i forhold til køn, alder og sociale distinktioner - og Emilies bestræbelser på, at finde engagement gennem at forstyrre disse normer, taler ind i Deleuze og Guattaris ide om kroppens sundhed som en politisk proces:

"Kroppens 'sundhed' er resultatet af alle disse kolliderende og opponerende relationer, biologiske kapaciteter eller kulturelle mind-sets [...] Sundhed er hverken en absolut (inden for enhver form for disciplin), som man kan stræbe imod, eller et idealiseret resultat af "sindet-over-materien". Det er en tilblivelsesproces som krops-selv, af samlende affekter og relationer, af modsætten sig fysisk eller social belejring og eksperimenteren med, hoad der er, og hoad der måtte blive" (min oversættelse, Fox 2002: 360).

Men ikke alle elever kunne mobilisere hverken den sanselige, sociale eller politiske krops begær og bestræbelse imod et sundhedsengagement, eller møde oplevelser af udefrakommende belejringer med af- eller gen-belejringer. Amina fortalte under et interview: "Helt ærligt, så føler jeg mig dum og mangler selvtillid [...] jeg tænker meget på, hvordan andre opfatter mig [...] men jeg er ikke typen, der motionerer meget [...] det eneste jeg gør, er at sidde derhjemme og lave lektier eller bare slappe af [...] mine forældre vil have, at jeg laver sport, men jeg ved simpelt- 
hen ikke, hvordan jeg skal få mig selv i gang [...] jeg har på en måde accepteret, at det ikke bliver mig, der tager skridtet." Tilsyneladende belejret af magtstrukturer omkring kropsstørrelse, skønhedsnormer og normer omkring passende elevhed, følte Amina sig ude af stand til at danne affektive relationer, som hun associerede med sundhed. Hun, og andre af eleverne, oplevede, at sundhed ikke kun stillede krav om disciplineret adfærd, men også om, at de skulle nyde denne adfærd. Oplevelsen af ikke at leve op til disse normer skabte både skam og frustration hos dem, som følelser, de følte de stod alene med (Vitus, 2017).

\section{Konklusion}

Analysen identificerede med omdrejningspunkt i forskellige kropssubjekter (den sanselige, sociale og politiske krop) gymnasieelevers forskellige affektive relationer og engagementer, som, de oplevede, gav dem sundhed - forstået som kraft, vitalitet og oplevelsen af nye muligheder for, hvem de kan være, og hvad deres kroppe kan gøre. I sanselige engagementer oplevede eleverne fordybelse og forbundethed til sig selv og hverdagslivets gøremål gennem affektive relationer til mennesker, materialiteter og aktiviteter. Kollektive engagementer var støttende i forhold til oplevelsen af sammenhold, tilhørsforhold og tilpasning til og deltagelse i fællesskaber. Kropspolitiske engagementer etablerede både socialt bekræftende relationer til og modstand gennem af-belejring i forhold til forskellige magtstrukturer, normer og diskurser om krop, køn og elevhed, og gen-belejring i nye relationer for at genvinde kraft.

I disse dynamikker synes centrale aspekter af gymnasielivet at stå i modsætning til elevernes engagementer, og fravriste dem oplevelsen af vitalitet, kapacitet og, i sidste instans, sundhed. Stress over skolelivet, oplevet som mangel på tid og mulighed for fordybelse i skolearbejdet, skabte en følelse af at blive afkoblet fra kroppen. Dette førte til mangel på motivation, både i forhold til skolearbejdet og fysiske aktiviteter, fx sport. For eleverne var sundhed ikke realiseret så meget igennem hoad de gjorde med eller ved deres krop, som hvordan (fx intensiteter, tempi og rytme) og med hvem (i fællesskaber bl.a. med andre unge). Det stærke fokus på individualisme, kvantitet, præstation, regulering og regler - som i stigende grad præger sundhedsdiskurser og skolepolitikker - frem for kollektivitet, kvalitet, oplevelse, relationer og rytmer, synes således at modarbejde elevernes engagementer $\mathrm{i}$ at praktisere og stræbe mod sundhed. Når kroppene fastlåstes i strukturer, som opleves som udefrakommende, reagerede nogle elever med di- 
rekte modstandsstrategier ved at skabe individuelle og kollektiv rum, hvor magten over kroppe blev tilbagetaget; mens andre gav helt slip på deltagelsen i egen kropssubjektivering, og således også i deres egen sundhed.

Deleuze og Guattaris perspektiv sætter fokus på forståelsen af gymnasieelevernes egne konstruktioner af det sunde liv og på de forhindringer, som begæret efter sundhed møder i deres dagligliv. Med dette perspektiv kan vi undersøge hvad kroppe kan gøre, ved at se på kroppes relationer og engagementer, ikke som styret mod årsag og effekt, men drevet af handling og affekt (Buchanan, 1997: 74). Studiet her illustrerer vigtigheden af at gymnasier (og andre ungdomsuddannelser) faciliterer læringsmiljøer, som muliggør elevernes udforskning af potentialerne i deres kroppes og intellekters kapaciteter, på måder, hvor de oplever, at de selv er med til at sætte præmisserne. Desuden har studiet understøttet anden forskning som peger på behovet for, at uddannelsesinstitutioner og sundhedsfremmeaktører overskrider det altoverskyggende fokus på individet og individualitet, og i stedet faciliteterer kollektive rum for kropsliggjort læring (bl.a. Hutters \& Murning, 2013; Jensen 2009b). Dette i en erkendelse af at motivation, engagement og myndiggørende, styrkende affektive relationer - i sundhed, krop og skolearbejde - hviler på en sam-produktion af engagementer.

\section{Noter}

${ }^{1}$ Jeg forstår her diskurs som en måde at tale om sundhed, som sætter bestemte betingelser for forståelsen af, hvad sundhed er, hvorfra sundhed udspringer, hvordan det opleves, og hvem der har magt og autoritet til at bestemme og udpege sundhed. En diskurs om sundhed sætter således ikke kun rammerne for hvordan sundhed sprogligt defineres, men også for hvilken viden, der har legitimitet i forståelsen af sundhed og hvilke praktikker, sundhed forudsætter.

${ }^{2}$ For en kritik af 'the components approach', se Atkinson, 2013; Atkinson and Joyce, 2011.

${ }^{3}$ Se http://sundhedsstyrelsen.dk/da/sundhed/puljer-og-projekter.

${ }^{4}$ Fx Ungeprofilundersøgelsen, se https://skolesundhed.dk/Public/Unge/Undersoegelser.aspx, og Den Nationale Sundhedsprofil Unge, se https://www.sst.dk/da/ planlaegning/kommuner/den-nationale-sundhedsprofil/unge-2011, http://www. danskernessundhed.dk/

${ }^{5}$ Står for Kost-Rygning-Alkohol-Motion. 
${ }^{6}$ Fx spiser mere frugt (p. 115), drikker færre sodavand (p. 119) og spiser morgenmad oftere (p. 111).

${ }^{7}$ En "almendannende og studieforberedende" temauge.

\section{Referencer}

Alderson, Priscilla and Morrow, Virginia (2004) Ethics, Social Research and Consulting with Children and Young People. Ilford: Barnardo's.

Atkinson, Sarah (2013) Beyond Components of Wellbeing: The Effects of Relations and Situated Assemblages. Topoi 32: 137-144. https://doi.org/10.1007/s11245-013-9164-0

Atkinson S, Joyce KE (2011) The place and practices of wellbeing in local governance. Environ Plan C 29:133-148 https://doi.org/10.1068/c09200

Bendtsen, Pernille, Mikkelsen, Stine Schou and Tolstrup, Janne S (2014) Ungdomsprofilen 2014. Sundhedsadfærd, helbred og trivsel blandt elever på ungdomsuddannelser. Statens Institut for Folkesundhed, Syddansk Universitet.

Bogue, Ronald (1989) Deleuze and Guattari. London: Routledge.

Buchanan, Ian (1997) The problem of the body in Deleuze and Guattari, Or, what can a body do? Body \& Society 1997(3): 73. https://doi.org/10.1177/1357034X97003003004

Caspi, A., G.H. Elder Jr. \& E.S. Herbener (1990) Childhood Personality and the Prediction of Life-Course Patterns. I: Robins, L. \& M. Rutter (red.): Straight and Devious Pathways from Childhood to Adulthood. Cambridge, MA: Cambridge University Press. S. 13-35.

Deleuze, Gilles (1988) Spinoza: Practical Philosophy. San Francisco, CA: City Lights.

Deleuze, Gilles (1990) The Logic of Sense. New York, NY: Columbia University Press.

Deleuze, Gilles and Guattari, Felix (1987) A Thousand Plateaus. Minneapolis, MN: University of Minnesota Press.

Fox, Nick J (2002) Refracting health: Deleuze, Guattari and body/self. Health 6(1): 347-364. https://doi.org/10.1177/136345930200600306

Fox, Nick J and Ward, Katie (2008) What are health identities and how may we study them? Sociology of Health E Illness 30: 1007-1021. DOI: 10.1111/j.1467-9566.2008.01093.x.

Guillemin, Marilys and Drew, Sarah (2010) Questions of process in participant-generated visual methodologies. Visual Studies 25(2): 175-188. https://doi.org/10.1080/147258 6X.2010.502676

Harper, Douglas (2002) Talking about pictures: A case for photo elicitation. Visual Studies 17(1). https://doi.org/10.1080/14725860220137345

Haug, Frigga (1992) Beyond Female Masochism - Memory-Work and Politics. London: Verso.

HBSC (2016) Growing Up Unequal. Health Behaviour in School-Aged Children. HBSC.

Hutters, Camilla og Murning, Susanne (2013): Klasserumsklima som betingelse for elevernes læring i gymnasiet i Dansk Pædagogisk Tidsskrift, Tema: Samværets pædagogik. Nr. 3, september 2013.

Ingholt, Liselotte (2007) Fællesskaber, vaner og deltagelse. Et studie af unge på to gymnasier. Ph.d. afhandling Institut for Psykologi, Københavns Universitet.

Krøjer, Jo and Hutters, Camilla (2006) Metodehåndbog i fortælleværksteder. Jelling: Folkehøjskolernes Forening i Danmark. 
Jensen, Anne Maj and Lagermann, Laila Colding (2017) Stress i gymnasiet. DPU, Aarhus Universitet.

Jensen, B.B. (2009a). Sundhedspædagogiske kernebegreber. I Kamper-Jørgensen, Almind og Jensen (red.) Forebyggende Sundhedsarbejde. Munksgaard. København: Munksgaard.

Jensen, B.B. (2009b). Sundhedspædagogik og intervention. I: Forebyggende Sundhedsarbejde Munksgaard, (Kamper-Jørgensen, Almind og Jensen (red.). København: Munksgaard.

Murning, Susanne og Camilla Hutters (2014) Klasserumskultur, inklusion og fraværsbekæmpelse. Tværgående erfaringer fra 12 udviklingsprojekter i gymnasiet. CeFU, Aalborg Universitet.

Nordahl, T. et al (2010): Uligheder og variationer. Danske elevers motivation, skolefaglig læringsudbytte og sociale kompetencer. Høgskolan i Hedemark og University College Nordjylland.

Pedersen, Ove Kaj (2011) Konkurrencestaten. Hans Reitzels Forlag.

Pedersen, Sofie (2015) The ought to be, how to be, or not to be. PhD Dissertation, Department of Psychology, University of Copenhagen.

Scheper-Hughes, Nancy and Lock, Margaret M (1987) The mindful body: A prolegomenon to future work in medical anthropology. Medical Anthropology Quarterly 1(1): 6-41. https://doi.org/10.1525/maq.1987.1.1.02a00020

Sundhedsstyrelsen (2004) Så gør det dog! For børn og Unge - forebyggelse i kommunerne. København: Sundhedsstyrelsen og Embedslægerne.

Sørensen, Niels Ulrik; Hutters, Camilla; Katznelson, Noemi; og Juul, Tilde Mette (2013) Unges motivation og læring. Copenhagen: Hans Reitzels Forlag.

Sørensen, Niels Ulrik; Grubb, Ane; Madsen, Iben Warring; og Nielsen, Jens Christian (2011) Når det er svært at være ung i DK - unges beretninger om mistrivsel og ungdomsliv. Center for Ungdomsforskning. Aalborg Universitet.

Timmerman, Stefan and Tavory, Iddo (2012) Theory construction in qualitative research: From grounded theory to abductive analysis. Sociological Theory 30(3): 167-186. Timmerman, Stefan and Tavory, Iddo (2012) Theory construction in qualitative research: From grounded theory to abductive analysis. Sociological Theory 30(3): 167-186. https:// doi.org/10.1177/0735275112457914

Tørslev, Mette Kirstine (2017), 'Feeling included' during early youth. A practice study of emotional wellbeing and ethnic disparities in school mental health. PhD Thesis, Department of Public Health, University of Copenhagen.

Tørslev, Mette Kirstine; Norredam, Marie \& Vitus, Kathrine (2017a): Becoming (ethnic minority) teenagers: a practice study of emotional well-being at a Danish sports school. Children's Geographies. Doi: 10.1080/14733285.2017.1287341.

Tørslev, Mette; Nørredam, Marie and Vitus, Kathrine (2017b) Exploring foodscapes at a Danish Public School: How emotional spaces influence students' eating practices. Food, Culture and Society, 20:4, pp. 587-607. Doi: 10.1080/15528014.2017.1357946.

Tørslev, Mette; Nørredam, Marie and Vitus, Kathrine (2017c) Doing race and ethnicity exploring the lived experience of whiteness at a Danish Public School. Whiteness $\mathcal{E}$ Education, vol. 1(2). Doi: 10.1080/23793406.2016.1260045.

UNI-C (2009): Frafald på de gymnasiale uddannelser. Del 2.

UVM (2015) Den årlige trivselsmåling.

Vallgårda, Signild (2010). Health policy. I: Vallgårda, S and Krasnik, A (eds) Health

Vallgårda, Signild (2011). Addressing individual behaviours and living conditions: Four 
Nordic public health policies. Scandinavian Journal of Public Health 39(6_Suppl): 6-10. DOI: $10.1177 / 1403494810378922$.

Vitus, Kathrine (2017) Ideology and resistance in young people's experiences of health under the 'imperative of enjoyment'. Sociology of Health and Illness, vol. 39, no 8, pp. 1514-1528. doi: 10.1111/1467-9566.12611.

Vitus, Kathrine (2018) Students' health engagement and affective relations in Danish upper secondary school, Journal of Youth Studies. doi: 10.1080/13676261.2018.1461201.

Vitus, Kathrine; Tørslev, Mette Kirstine; Ditlevsen, Kia; Nielsen, Annemette (2017): Dilemmas of health responsibility in the Danish welfare state: body weight government of non-white ethnic minority children and young people. Critical Public Health, 0(0), 1-13. doi: 10.1080/09581596.2017.1286294. BFI- level 1.

Willer, Thomas \& Søren Østergaard (2017) Det er vigtigt at være en succes ... men det er bare ikke altid, at det lykkes! Ungdomsanalyse.nu. 